\title{
Article \\ Numerical Study of the In-Plane Seismic Response of RC Infilled Frames
}

\author{
Matteo Bagnoli ${ }^{1}$, Ernesto Grande ${ }^{1, *}$ and Gabriele Milani ${ }^{2}$ (D) \\ 1 Department of Sciences Engineering, University Guglielmo Marconi, Via Plinio 44, 00193 Roma, Italy; \\ 1xrmcj1bi@studenti.unimarconi.it \\ 2 Department of Architecture, Built Environment and Construction Engineering, Politecnico di Milano, \\ Piazza Leonardo da Vinci 32, 20133 Milano, Italy; gabriele.milani@polimi.it \\ * Correspondence: e.grande@unimarconi.it
}

check for updates

Citation: Bagnoli, M.; Grande, E.; Milani, G. Numerical Study of the In-Plane Seismic Response of RC Infilled Frames. Constr. Mater. 2021, 1, 82-94. https://doi.org/10.3390/ constrmater1010006

Received: 6 April 2021

Accepted: 13 May 2021

Published: 18 May 2021

Publisher's Note: MDPI stays neutral with regard to jurisdictional claims in published maps and institutional affiliations.

Copyright: (c) 2021 by the authors. Licensee MDPI, Basel, Switzerland. This article is an open access article distributed under the terms and conditions of the Creative Commons Attribution (CC BY) license (https:// creativecommons.org/licenses/by/ $4.0 /)$.

\begin{abstract}
Reinforced Concrete (RC) buildings with masonry infills are a very common structural typology worldwide for civil, strategic, or productive use. Damage to infills may cause danger for human lives and strongly affects economic losses, as shown during past earthquakes. In the current literature, different approaches are available for modeling the in-plane response of infilled frames and different constitutive laws generally calibrated on experimental tests. On the contrary, few and recent studies proposed formulas that account for the main properties of infills influencing their in-plane behavior to lateral forces. This paper presents a study finalized to derive a reliable model that is able to predict the monotonic and cyclic response of RC infilled masonry frames. To this end, after a critical analysis of the available literature, the authors combine among them two models, one for the monotonic response and the other for the cyclic one, by showing their reliability with reference to different experimental cases. Then, at the end of the paper, the derived models are employed to assess the seismic vulnerability of infills throughout a proposed procedure based on the common pushover analysis approach.
\end{abstract}

Keywords: infilled RC frames; pushover; damage assessment

\section{Introduction}

Regarding the modeling of infill panels, there are two different main approaches generally called micro-modeling and macro-modeling. The main differences between them are the accuracy and computational effort. Indeed, while the micro-modeling takes into consideration all the components (blocks, mortar, etc.), the macro-modeling considers the entire masonry panel as a homogenous unit. The latter is generally used in case of the global response, and its influence of the behavior of RC infilled frames is considered [1].

In recent decades, many studies concerning the behavior of steel or reinforced concrete infilled frames have been carried out. Among these, in [2-6], specific tests were carried out to understand the behavior of the infill frames by performing experimental and analytical studies.

In particular, in [2], it was underlined the interaction between the infill panel and the members of the frame occurring at compression zones. In [3], it was suggested to model the infill panel as an equivalent diagonal strut by assuming a width equal to $1 / 3$ of the length of the diagonal strut itself.

In [6], the author proposed an empirical formula for evaluating the width of the equivalent strut: the same formula was proposed in FEMA codes 274, 306, and 356 [7-9]. An in-depth study concerning this aspect was carried out in [10] who assessed the influence of beam and column dimensions on the width of the equivalent strut.

Other researchers focused on the use of multiple struts for modeling the infill panels. Among these, in [11], the author analyzed the efficacy of models with multiple equivalent struts in predicting the response of reinforced concrete frames with infill panels. 
Currently, as testified by current studies, the model with single or multiple equivalent diagonal struts is widely employed for studying the response of RC infilled frames. Nevertheless, the attention of the majority of available studies is focused on the derivation of constitutive laws able to capture the main damage phases characterizing the behavior of infill masonry panels. Among these, in [12,13], the researchers proposed formulas for deriving the main parameters characterizing the monotonic and cyclic behavior response of infill panels when the equivalent diagonal model is employed. In both studies, as in other current ones, a multilinear constitutive law based on the pinching material model proposed in [14] is accounted for schematizing strength and stiffness degradation due to the progressive damage. Although this constitutive model requires a significant number of parameters, particularly for describing the cyclic response, it allows simulating the response of infill panels satisfactorily.

The study here presented is finalized to assess the reliability of a constitutive model for reproducing the monotonic and cyclic response of infill panels, which are obtained by opportunely combining among the outcomes of studies of the literature. Then, numerical analyses are performed in order to assess the reliability of the proposed model by comparing the monotonic and cyclic numerical response with the experimental one of case studies.

\section{Infills Modeling Approach}

The constitutive model here proposed for schematizing the behavior in terms of force-deformation of the equivalent strut is derived by combining among them the model proposed in [12] and the one proposed in [13].

Regarding the study proposed in [13], some formulas for evaluating a simplified multilinear constitutive law, which explicitly considers the main geometric and mechanical parameters of infill panels, were proposed. Indeed, the formulas were deduced from a multivariate regression analysis considering a database composed of 264 infilled frames (191 RC frames and 73 steel frames) subjected to monotonic and cyclic load conditions.

The formulas deduced in this study are here considered for the characterization of the monotonic behavior of infill panels, i.e., to derive the backbone force-displacement curve. In particular, considering the multilinear law presented in Figure 1, the following formulas were proposed in [13]:

$$
\begin{gathered}
\mathrm{K}_{\mathrm{e}}=0.0143 \cdot \mathrm{E}_{\mathrm{m}}{ }^{0.618} \cdot \mathrm{t}_{\mathrm{w}}{ }^{0.694}\left(\mathrm{~h}_{\mathrm{w}} / \mathrm{l}_{\mathrm{w}}\right)^{-1.096} \\
\mathrm{~F}_{\mathrm{c}}=0.003766 \cdot \mathrm{f}_{\mathrm{m}}{ }^{0.196} \cdot \mathrm{t}_{\mathrm{w}}{ }^{0.867} \mathrm{l}_{\mathrm{d}}{ }^{0.792} \\
\mathrm{~F}_{\mathrm{y}}=0.72 \cdot \mathrm{F}_{\mathrm{c}} \\
\mathrm{F}_{\mathrm{res}}=0.4 \cdot \mathrm{F}_{\mathrm{c}} \\
\mathrm{d}_{\mathrm{c}}=\mathrm{l}_{\mathrm{d}} \cdot 0.0154 \mathrm{E}_{\mathrm{m}}{ }^{-0.197}\left(\mathrm{~h}_{\mathrm{w}} / \mathrm{l}_{\mathrm{w}}\right)^{-0.978} \\
\mathrm{~K}_{\mathrm{pc}}=\mathrm{K}_{\mathrm{e}}-1.278 \mathrm{f}_{\mathrm{m}}{ }^{-0.357} \cdot \mathrm{t}_{\mathrm{w}}{ }^{-0.517} \\
\mathrm{~d}_{\mathrm{y}}=\mathrm{F}_{\mathrm{y}} / \mathrm{K}_{\mathrm{e}}
\end{gathered}
$$

where $E_{m}$ is the modulus of elasticity of the masonry material composing the panel; $f_{m}$ is the compressive strength of the panel; $\mathrm{t}_{\mathrm{w}}, \mathrm{l}_{\mathrm{w}}$, and $\mathrm{h}_{\mathrm{w}}$ are respectively the thickness, length, and height of the panel; $l_{d}$ is the length of the diagonal equivalent to the panel. The other symbols are shown in Figure 1.

The above equations allow numerically analyzing the monotonic static response of $\mathrm{RC}$ infilled frames by taking into account the geometric (dimensions) and mechanical properties of infill panels.

On the other hand, regarding the behavior of infill panels toward cyclic actions, the complexity of phenomena related to stiffness and strength degradation, and pinching effects does not allow deriving reliable formulas related to the characteristics of the infill. Indeed, the majority of studies generally provide laws deduced from calibration processes. 
In particular, among the recent ones, in the study carried out in [12], the researchers proposed a set of parameters deduced from a calibration process to model the cyclic behavior of infills throughout the pinching 4 model available in the computer code [15].

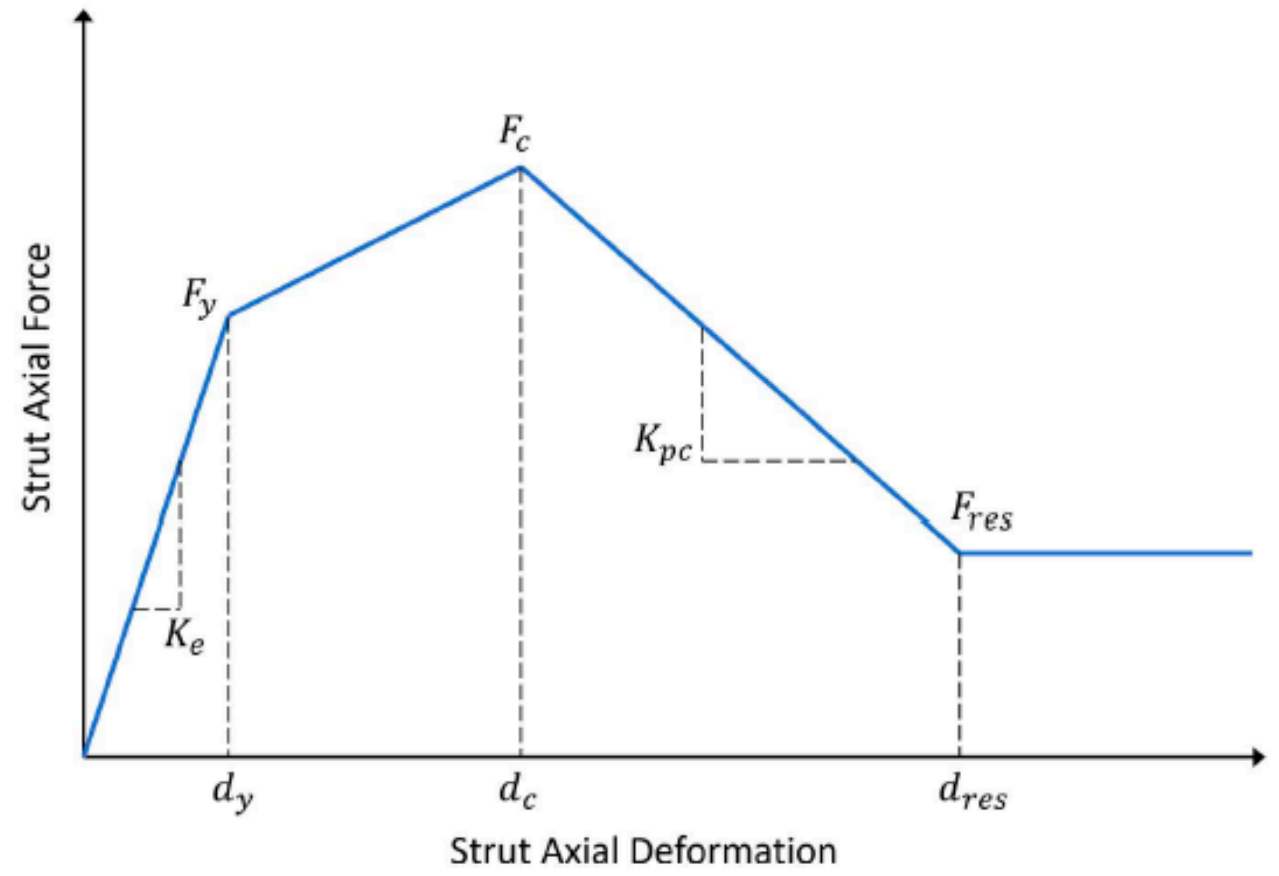

Figure 1. Multilinear law selected for infills according to the pinching 4 model available in OpenSees.

The present research combines together the formulas proposed in [13] and the parameters proposed in [12] to derive a reliable model for the numerical analysis of RC infilled frames. The reliability of the derived model is assessed with reference to some experimental cases and, in addition, it has been employed to evaluate the vulnerability of infills toward seismic actions throughout a procedure based on the common pushover analysis approach.

Finite element analyses are carried out by using the software Opensees [15] where the proposed model has been introduced by using the pinching 4 model. In addition, a subroutine developed in [16] has been carried out for the procedure finalize to assess the vulnerability of infills toward seismic actions.

\section{Case Studies}

The case studies that here accounted for the validation of the proposed model (see Figure 2) are derived from the experimental studies carried out in [17-20].

Regarding the study conducted in [17], the accounted frame was characterized by a height of $1.80 \mathrm{~m}$ and a length of $2.40 \mathrm{~m}$. The column and beam cross-sections had, respectively, $0.15 \mathrm{~m} \times 0.15 \mathrm{~m}$ and $0.15 \mathrm{~m} \times 0.20 \mathrm{~m}$ dimensions. The columns were reinforced with eight longitudinal bars of diameter $10 \mathrm{~mm}$. The beam was reinforced with six longitudinal bars with diameter $8 \mathrm{~mm}$. The infill was built with $0.30 \mathrm{~m} \times 0.20 \mathrm{~m} \times 0.15 \mathrm{~m}$ horizontally hollow bricks, usual in Portugal, bedded by using mortar. Experimental tests were performed by applying at the top of the frame a history of horizontal displacements devoted to analyzing the cyclic response of the frame.

The study conducted by [18] concerned an experimental program consisting of three single-story, one-bay, 1/3-scale specimens. Both bare frames and infilled frame with clay brick solid masonry were considered in the study. The infill panel was built by using clay bricks type cut into two halves because of the scaled dimensions of the frame. In addition, in this case, experimental tests were performed by applying at the top of the frame a history of horizontal displacements. 


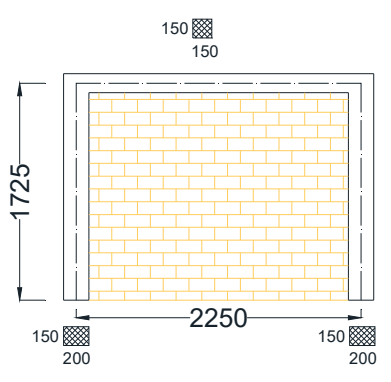

(a)

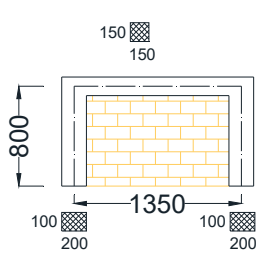

(b)

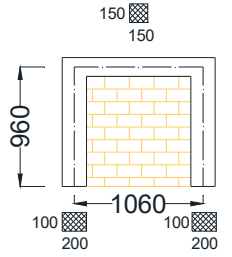

(c)

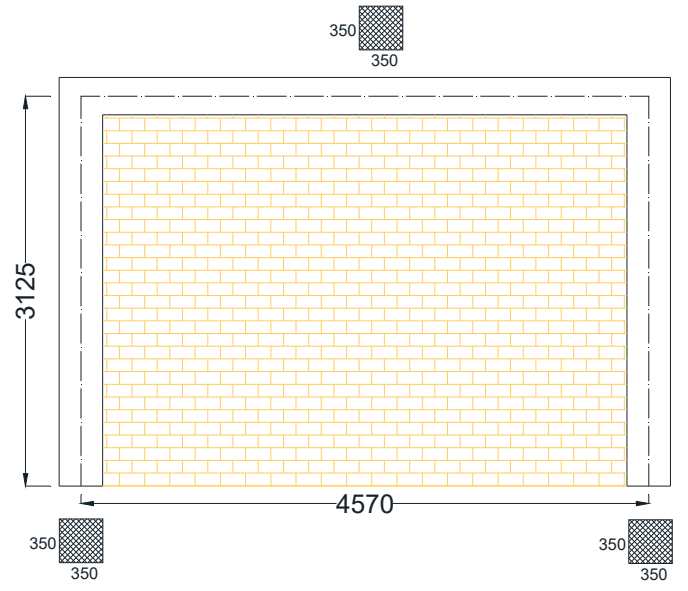

(d)

Figure 2. Schematization of the geometry of the accounted frames: (a) Pires et al. (1990) [17]; (b). Karayannis et al. (2005) [18]; (c). Stylianidis et al. (2012) [19]; (d). Morandi et al. (2018) [20].

The study carried out in [20] concerned experimental tests carried out on bare and fully or partially infilled full-scale single-storey, single-bay RC frames, designed according to European (and Italian) code provisions. Specifically, related to the cyclic in-plane tests, one RC frame was tested without infill up to maximum drift of $3.50 \%$ in order to reach the ultimate conditions of the specimen, while three fully infilled specimens were tested at three increasing maximum levels of drift, equal to $1.00,1.50$, and $2.50 \%$. Infills made of vertically hollowed lightweight tongue and groove clay block units (DANESI Poroton plan $700 \mathrm{TS}$ ), having nominal dimensions of $235 \times 350 \times 235 \mathrm{~mm}$, were used.

The main characteristics of infills of the accounted cases are summarized in Table 1.

Table 1. Main characteristics of infills that characterize the accounted specimens.

\begin{tabular}{|c|c|c|c|c|c|c|}
\hline Study & $\mathrm{E}_{\mathrm{m}}[\mathrm{MPa}]$ & $\mathbf{t}_{\mathrm{w}}[\mathrm{mm}]$ & $\mathbf{h}_{\mathrm{col}}[\mathrm{mm}]$ & $\mathrm{f}_{\mathrm{m}}[\mathrm{MPa}]$ & $\mathrm{h}_{\mathrm{w}}[\mathrm{mm}]$ & $\mathrm{l}_{\mathrm{w}}[\mathrm{mm}]$ \\
\hline $\begin{array}{l}\text { Pires et al. } \\
\text { (1990) [17] }\end{array}$ & 1840 & 50 & 1725 & 2.1 & 1625 & 2100 \\
\hline $\begin{array}{l}\text { Karayannis et al. } \\
\text { (2005) [18] }\end{array}$ & 660.66 & 160 & 900 & 2.63 & 800 & 1200 \\
\hline $\begin{array}{l}\text { Stylianidis et al. } \\
\text { (2012) [19] }\end{array}$ & 2310 & 63 & 1060 & 4.2 & 860 & 910 \\
\hline $\begin{array}{l}\text { Morandi et al. } \\
\text { (2018) [20] }\end{array}$ & 5299 & 350 & 3125 & 4.64 & 2950 & 4220 \\
\hline
\end{tabular}

In addition, Figure 3 depicts the constitutive laws that characterized the behavior of the equivalent struts corresponding to the different selected case studies. From the figure, it is evident the influence of both the geometry of the panel and the other characteristics, in particular the compressive strength, on both the initial stiffness and the axial compressive strength of the equivalent strut element. 


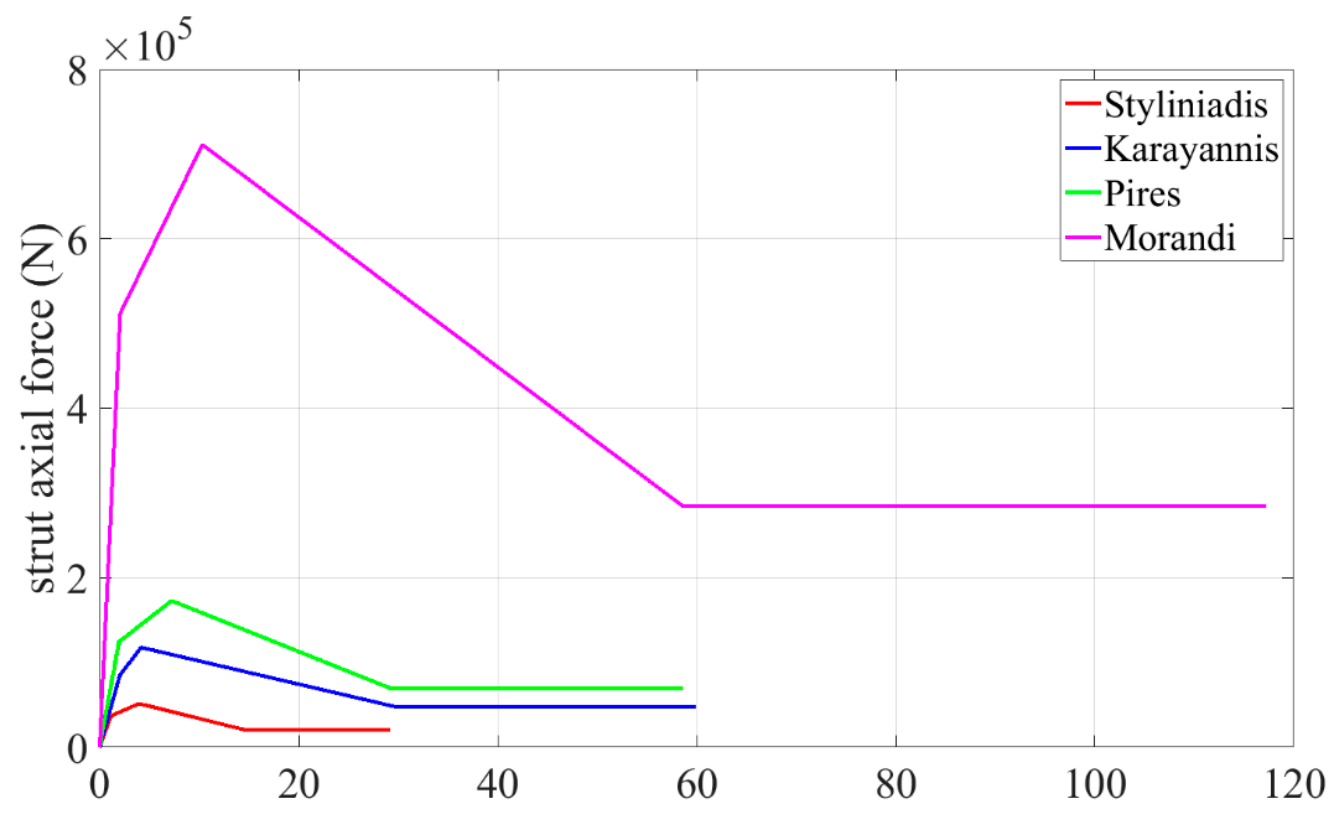

Figure 3. Multilinear laws obtained for the different selected cases.

\section{Modeling and Numerical Analyses}

Taking into account the model proposed in this paper for masonry infills and the cases selected for the literature, a validation is performed throughout numerical analyses carried out by the computer code Opensees [15].

In particular, regarding the FE modeling, a frame element approach has been adopted by schematizing the infill throughout the equivalent strut diagonal technique. The nonlinear behavior of both RC members (i.e., beam and columns) and infills has been considered by using a diffuse plasticity by a fiber discretization for beam and column members and a simple nonlinear link (twoNodeLink element [15]) for the equivalent strut diagonal.

Regarding column and beam elements, the force-based element, force Beam-Column in Opensees [15], was used to construct an object, which is based on the iterative forcebased formulation. A variety of numerical integration options can be used in the element state determination and encompass both distributed plasticity and plastic hinge integration. Gauss-Lobatto integration is the used approach for evaluating the response of these forcebased elements because it places an integration point at each end of the element, where bending moments are largest in the absence of interior element loads.

Concerning the materials used in the numerical simulations, uniaxial stress-strain concrete and steel materials were used to model the specimens at the section level, respectively Concrete04 and Steel02 in Opensees [15].

The Concrete04 model defines the uniaxial response of concrete both in compression and tension, using degraded linear unloading-reloading stiffness and tensile strength with exponential decay [15].

The Steel02 material model was employed to model the uniaxial cyclic behavior of reinforcing steel. This material is characterized by a bilinear backbone, described by an elastic-plastic law with an isotropic strain hardening [15].

Regarding the latter, according to the studies [12,13], the pinching 4 model available in the material library of Opensees has been employed. On the other hand, regarding the material models selected for the concrete and steel of beam and columns, the models concrete 04 and steel02, already available in the Opensees software library, were used, respectively. Nonlinear monotonic and cyclic analyses, the latter according to the experimental load protocol, have been performed by both considering the bare and the infilled frame configurations. The obtained results are reported in Figures 4-7 in terms of Base Shear-Top Displacement curves. In particular, the figures report both the response obtained by monotonically increasing the lateral force (plots on the left) and the cyclic response 
obtained by applying the experimental load protocol (plots on the right). The numerical curves (continuous red line) are compared with the envelope of the experimental response (dotted line).

Regarding the cyclic response, although in the present paper, the attention and the developed procedure is carried out by considering the monotonic response only, it has been also reported in order to assess the potentialities of the proposed model in case of cyclic forces also.

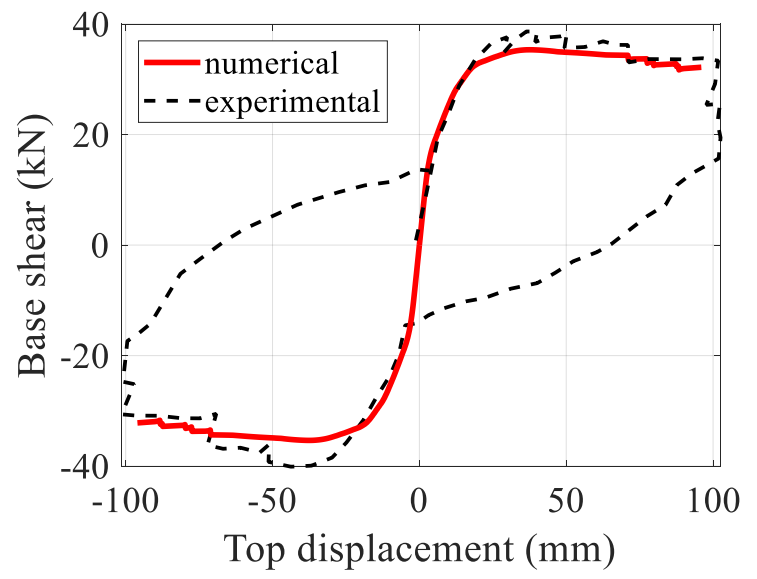

(a)

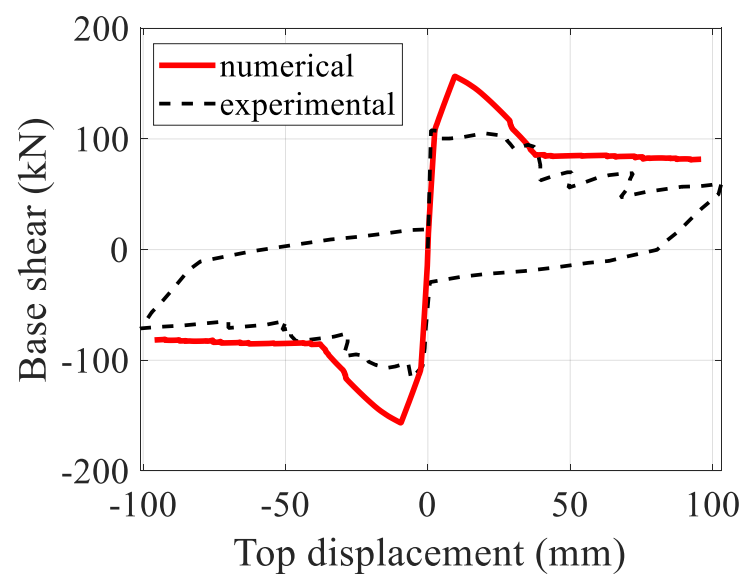

(c)

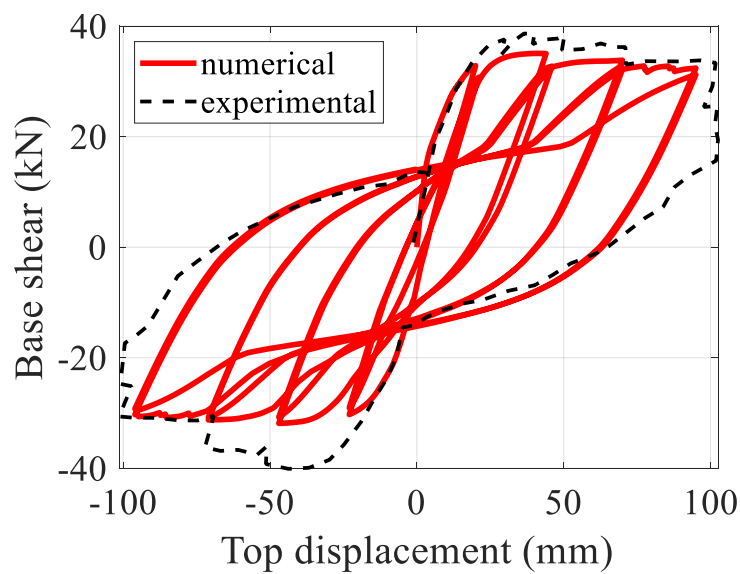

(b)

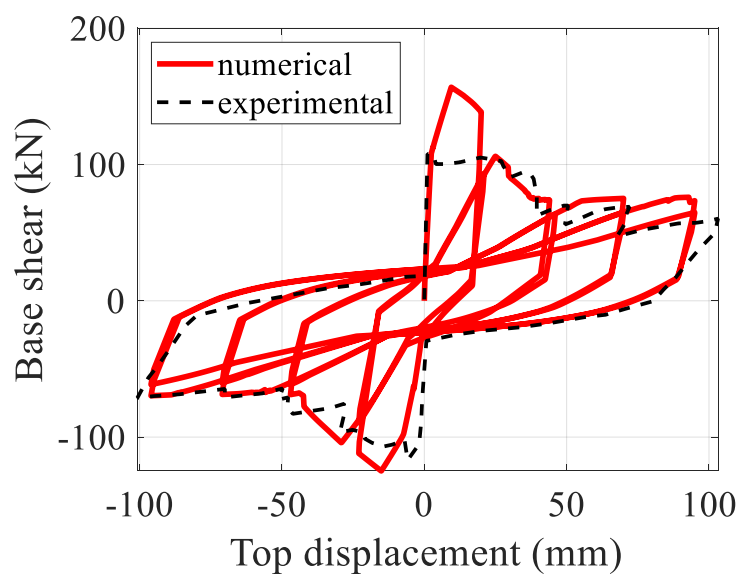

(d)

Figure 4. Results of monotonic (a,c) and cyclic (b,d) analyses for the frame analyzed by Pires et al. (1990) [17]: bare frame $(\mathbf{a}, \mathbf{b})$; infilled frame $(\mathbf{c}, \mathbf{d})$. 


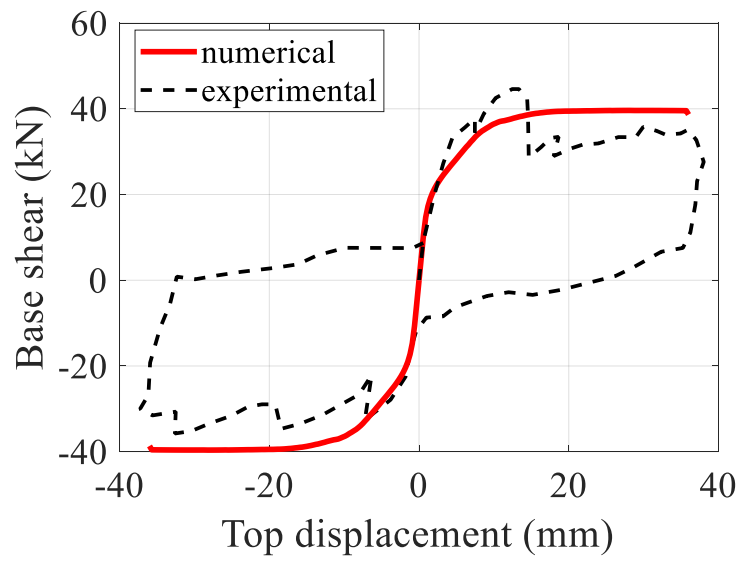

(a)

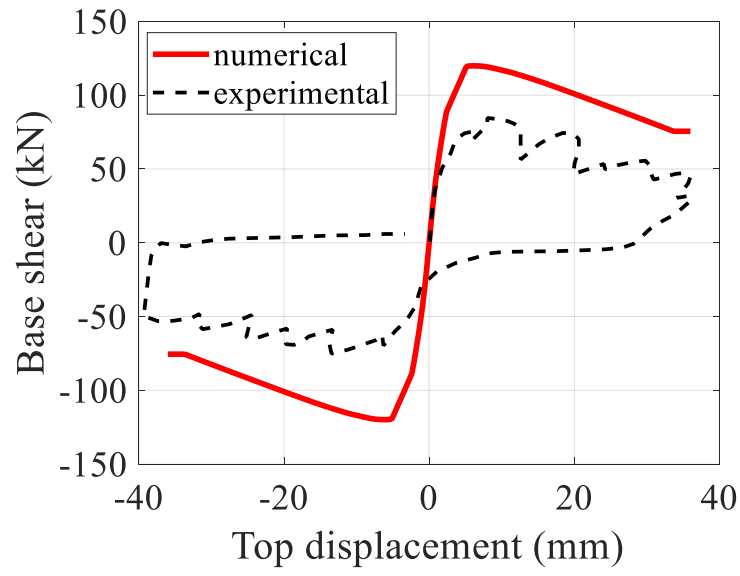

(c)

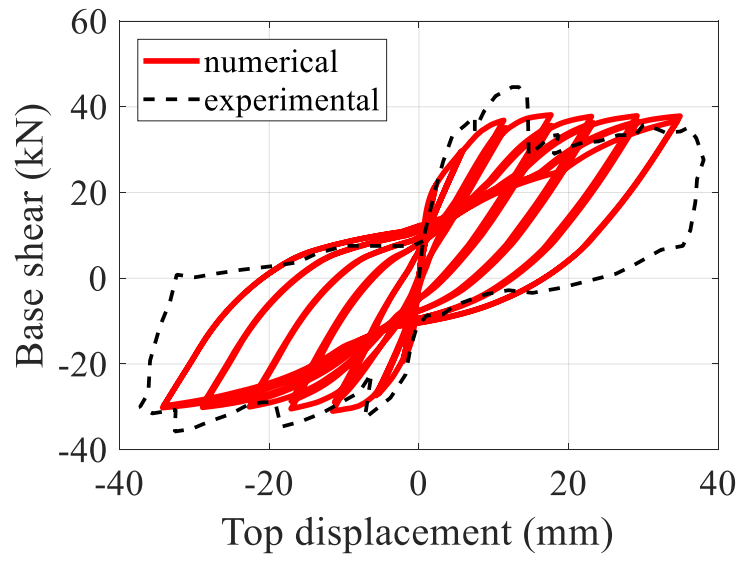

(b)

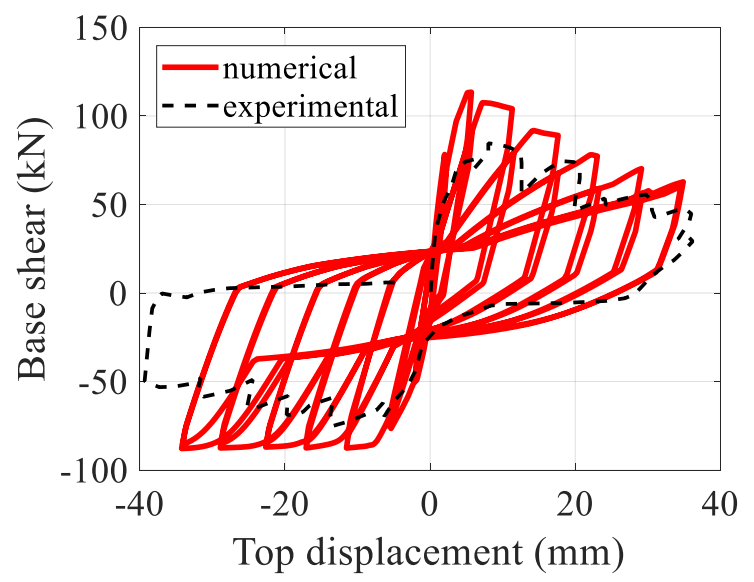

(d)

Figure 5. Results of monotonic (a,c) and cyclic (b,d) analyses for the frame analyzed by Karayannis et al. (2005) [18]: bare frame $(\mathbf{a}, \mathbf{b})$; infilled frame $(\mathbf{c}, \mathbf{d})$.

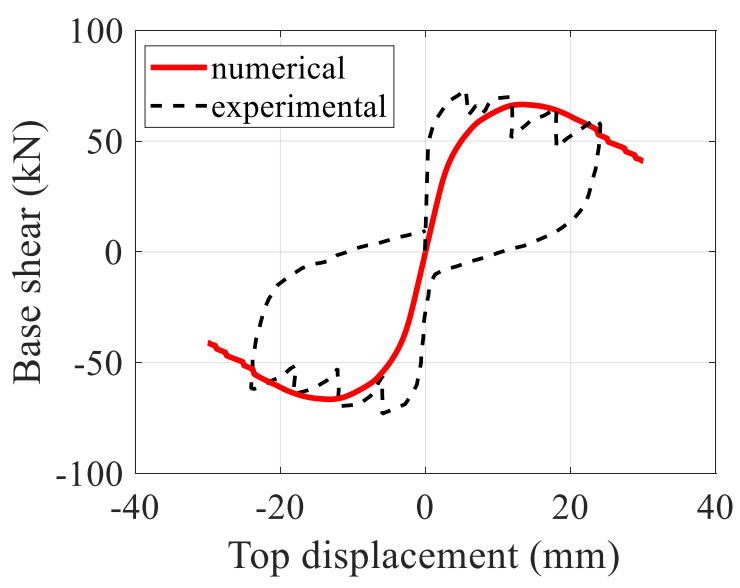

(a)

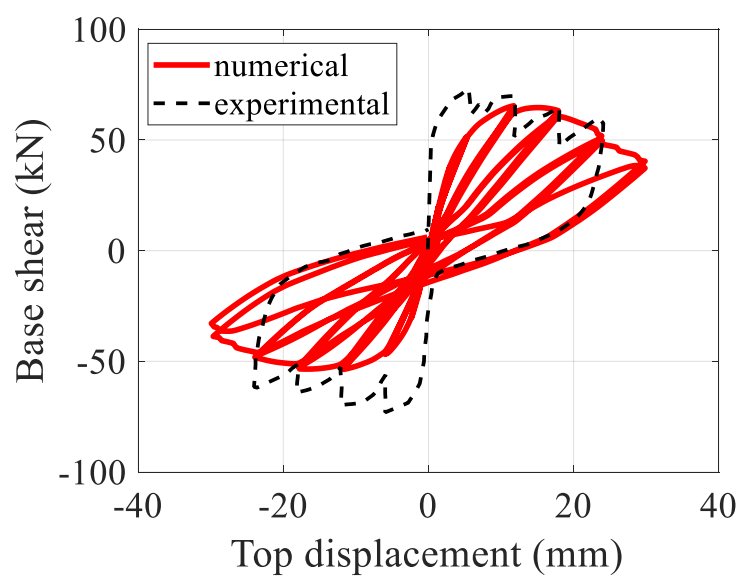

(b)

Figure 6. Cont. 


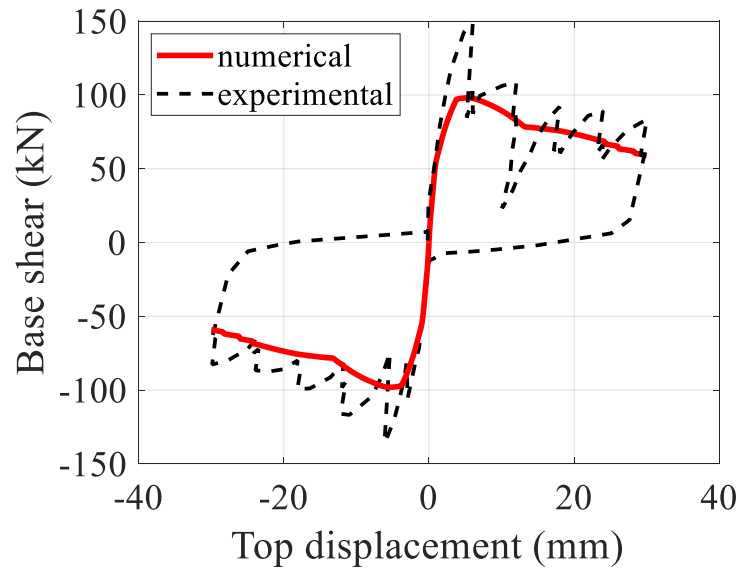

(c)

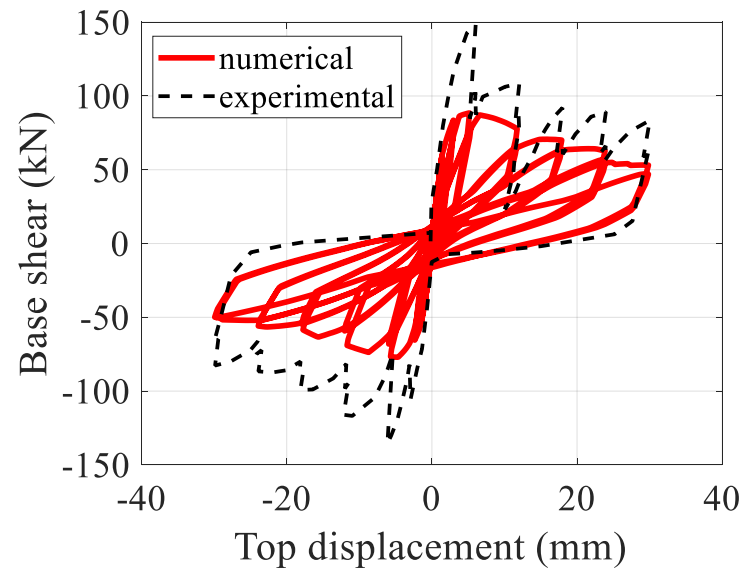

(d)

Figure 6. Results of monotonic $(\mathbf{a}, \mathbf{c})$ and cyclic $(\mathbf{b}, \mathbf{d})$ analyses for the frame analyzed by Stylianidis et al. (2012) [19]: bare frame (a,b); infilled frame $(\mathbf{c}, \mathbf{d})$.

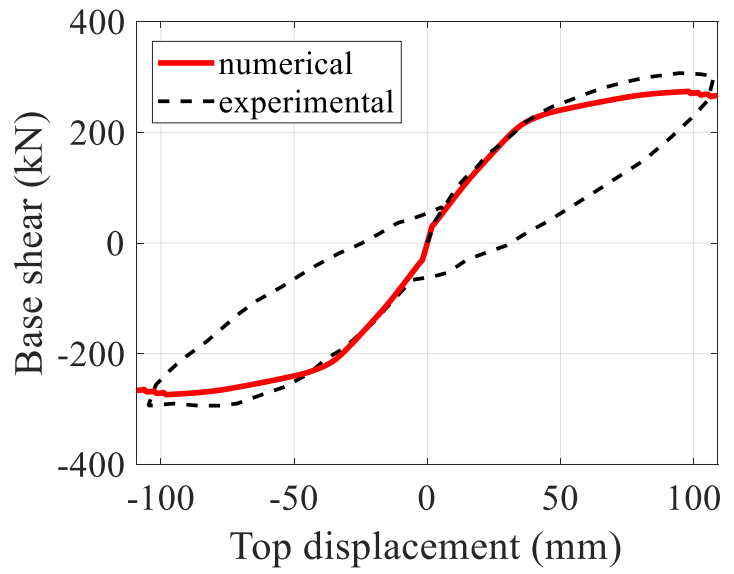

(a)

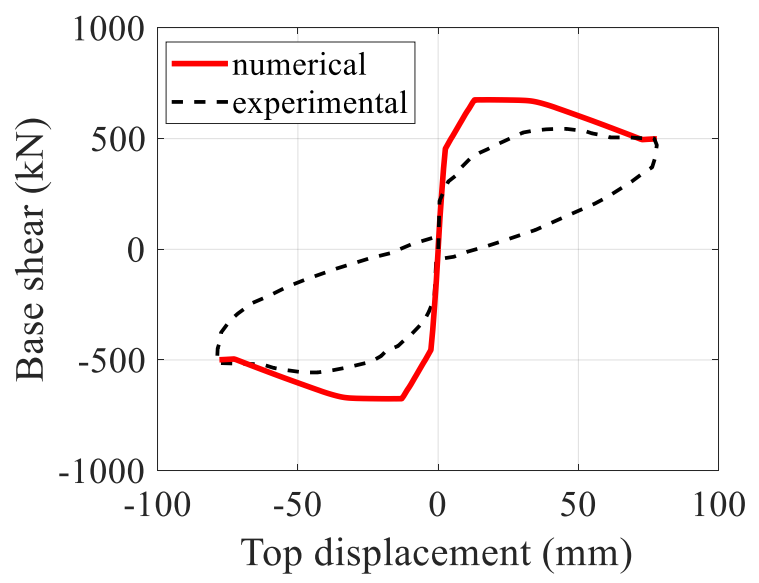

(c)

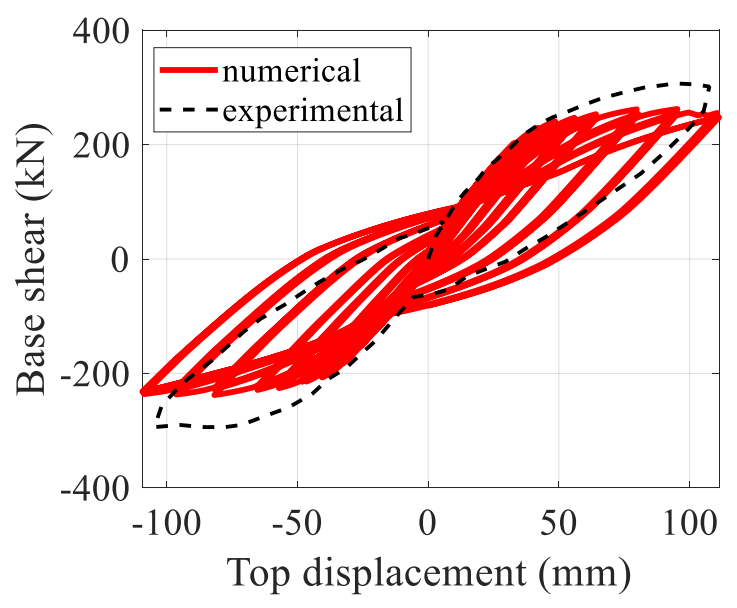

(b)

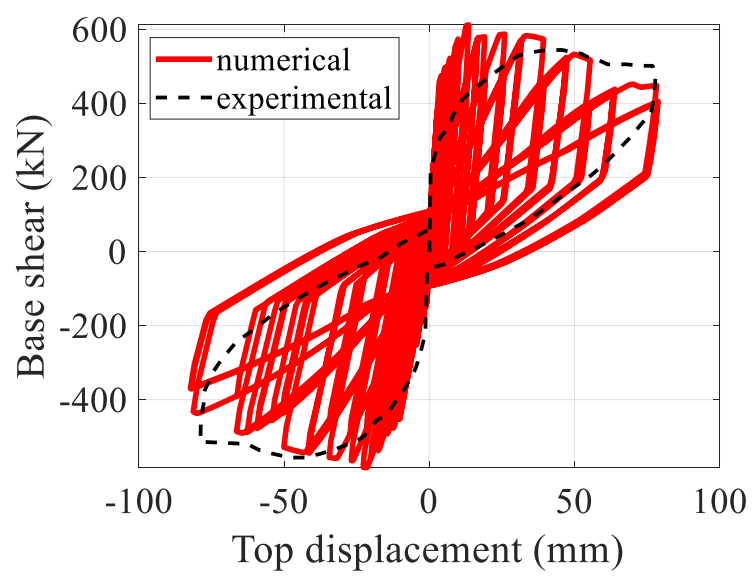

(d)

Figure 7. Results of monotonic (a,c) and cyclic (b,d) analyses for the frame analyzed by Morandi et al. (2018) [20]: bare frame $(\mathbf{a}, \mathbf{b})$; infilled frame $(\mathbf{c}, \mathbf{d})$.

Starting from the evidence that the model and parameters accounted for RC members allow obtaining a good simulation of the monotonic and cyclic response of RC bare frames, from the figures also emerge a good level of reliability of the proposed model in predicting 
the global response of RC infilled frames. Indeed, in the majority of the analyzed cases, the experimental global response of infilled frames is well reproduced in terms of pre and post-peak behavior both from monotonic and cyclic analyses.

\section{Damage Assessment of Infills toward Seismic Action}

The constitutive models presented in the previous sections for simulating the response of RC infilled frames are here employed for assessing the level of damage of infills toward seismic actions. To this end, a procedure based on the use of the common pushover analysis where the ultimate capacity of the RC infilled frame is set according to different damage states of the infill itself is proposed.

In particular, considering the multilinear constitutive law selected for describing the monotonic behavior of infill elements, two Limit States respectively corresponding to the attainment of the axial displacement of the equivalent strut equal to dy, i.e., the beginning of damaging of infill, and $1.5 \mathrm{dy}$, have been specifically considered in this paper [1]. Indeed, although the beginning of damage of infills is generally neglected since it does not significantly affect the structural performance of infills, it could influence the service performance particularly in the case of the presence of systems applied on infills for improving the energy efficiency of buildings.

Then, the aim of the proposed procedure is to correlate this level of damage of infills to the level of seismic actions. Then, the seismic vulnerability of infills with respect to this level of damage in case of low and medium-intensity seismic actions is here assessed.

To this end, a procedure based on the common approach proposed by codes for evaluating the seismic performance of $\mathrm{RC}$ frames by using the nonlinear static analysis (pushover) is here employed according to the two phases shown in Figure 8 (a. phase 1; b. phase 2) and considering the following steps:

- The limit state of the infill is preliminary set.

- A modal analysis of the infilled frame is performed in order to derive periods and modes of vibration: since this analysis is performed in the elastic field, the contribution of an equivalent strut only is considered.

- A subsequent pushover analysis of the infilled frame is performed by obtaining a capacity curve in terms of base shear-top displacement $\left(\mathrm{V}_{\mathrm{b}}-\mathrm{D}\right)$, which ends when the limit state of the infill is attained (capacity).

- The RC infilled frame is converted into a simplified single DOF system (substitute structure): this allows deriving the corresponding nonlinear capacity curve $\mathrm{V}^{*}{ }_{b}-\mathrm{D}^{*}$, which is subsequently simplified into a bilinear curve characterized by an equivalent stiffness (slope of the first branch) and the equivalent period of vibration of the substitute structure. Indeed, the substitute structure is an equivalent SDOF linear system, whose properties in terms of effective lateral stiffness and equivalent viscous damping are the same of the real structure at the design displacement response [21-24]. In the present paper, the transformation of the real one-story frame into the equivalent SDOF has been directly made by considering the period of vibration, the effective mass, and a damping values equal to $5 \%$.

- The elastic displacement response spectrum corresponding to the selected Peak Ground Acceleration (PGA) of the site can be used for deriving the seismic demand of the substitute structure in terms of spectral displacement. Then, after the derivation of the capacity curve of the real frame $\mathrm{V}_{\mathrm{b}}-\mathrm{D}$ from the curve $\mathrm{V}_{\mathrm{b}}{ }^{*} \mathrm{D}^{*}$, the ultimate displacement (capacity) of the real frame is obtained [23,24]. 


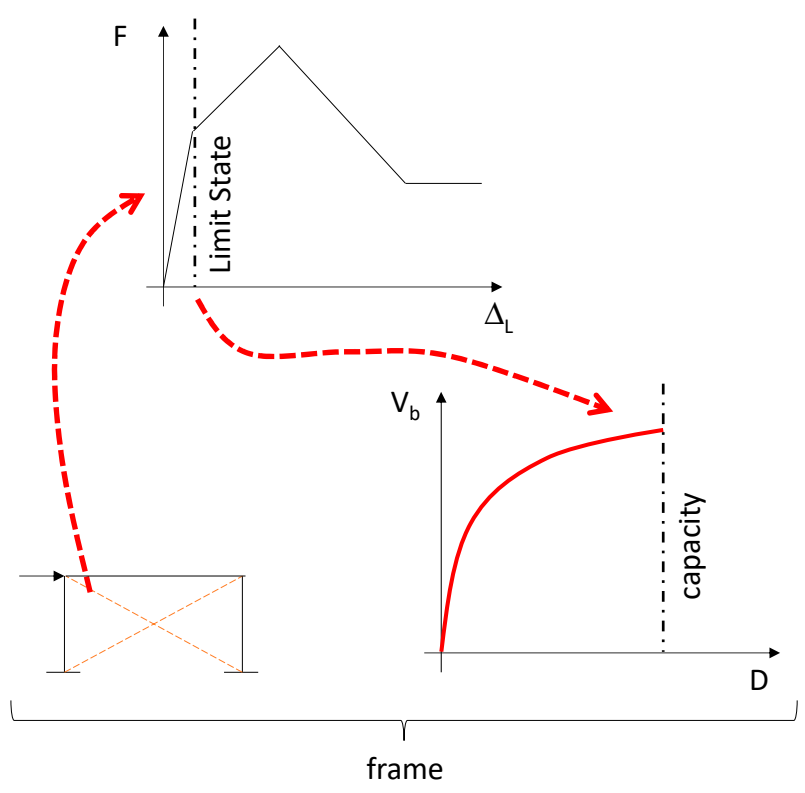

(a)

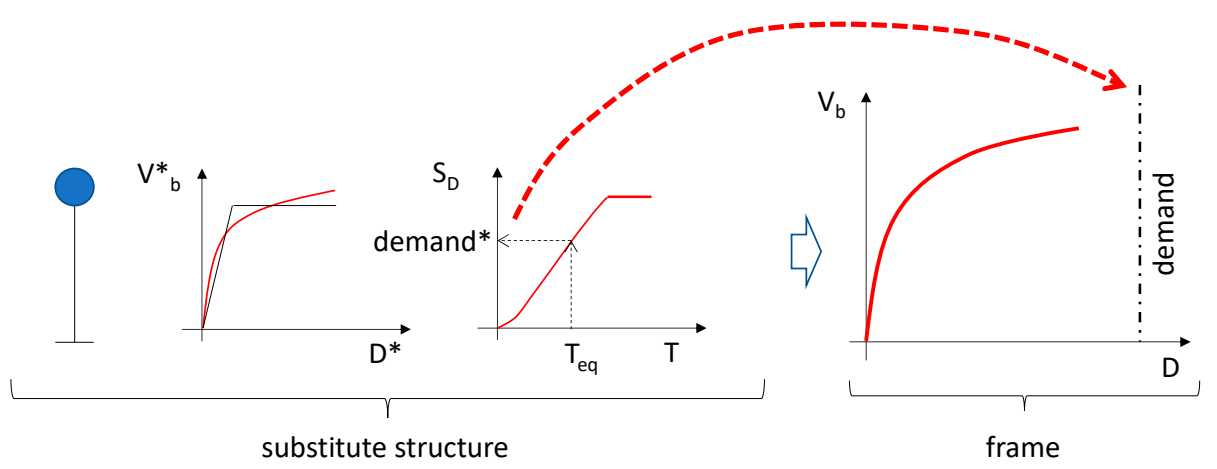

(b)

Figure 8. Schematization of the proposed procedure for assessing the damage of infills: (a) first phase; (b) second phase.

The proposed procedure has been applied to the frame analyzed in Morandi et al. (2018) [20] and Piers et al. (1990) [17] by considering four different values of masses in order to have a range of four values of the period of vibration between 0.1 and $0.2 \mathrm{~s}$ (obtained from the modal analysis where a linear behavior of the frame with a single strut only has been considered), which is common for one-story RC frames. Moreover, regarding the seismic actions, an Italian site near to L'Aquila (a city of central Italy recently stricken by a severe earthquake) has been selected by considering four PGA values corresponding to a range of return periods varying between 30 and 101 years according to the Italian code (see Table 2).

Figure 9 presents the results in terms of Damage Index assumed equal to the ratio between the seismic demand required to the infilled frame and the capacity corresponding to the attainment of the imposed limit states for the infill (both in terms of lateral top displacement). The indices with the lowest values correspond to a period of vibration of the frame equal to $0.1 \mathrm{~s}$. On the contrary, the highest values correspond to a period of vibration equal to $0.2 \mathrm{~s}$. 
Table 2. Parameters accounted for the numerical analyses.

\begin{tabular}{|c|c|c|c|}
\hline Site & $\begin{array}{l}\text { Longitude } \\
13.422\end{array}$ & $\begin{array}{l}\text { Latitude } \\
42.385\end{array}$ & $\begin{array}{l}\text { Soil type } \\
\text { C }\end{array}$ \\
\hline Seismic Action & $\begin{array}{l}\text { Return Time [year] } \\
\text { 30-50-72-101 }\end{array}$ & $\begin{array}{c}\text { PGA [g] } \\
0.1252-0.1618- \\
0.1875-0.2141\end{array}$ & - \\
\hline Mass $\left[\mathrm{Ns}^{2} / \mathrm{mm}\right]$ & $\begin{array}{c}\text { Morandi et al. (2018) [20] } \\
\text { 40-80-120-160 } \\
\text { Pires et al. (1990) [17] } \\
\text { 5-10-15-20 } \\
\text { Morandi et al. (2018) [20] } \\
\text { (bare)-Pires et al. (1990) [17] } \\
\text { (infill) } \\
\text { 8-32 }\end{array}$ & - & - \\
\hline
\end{tabular}

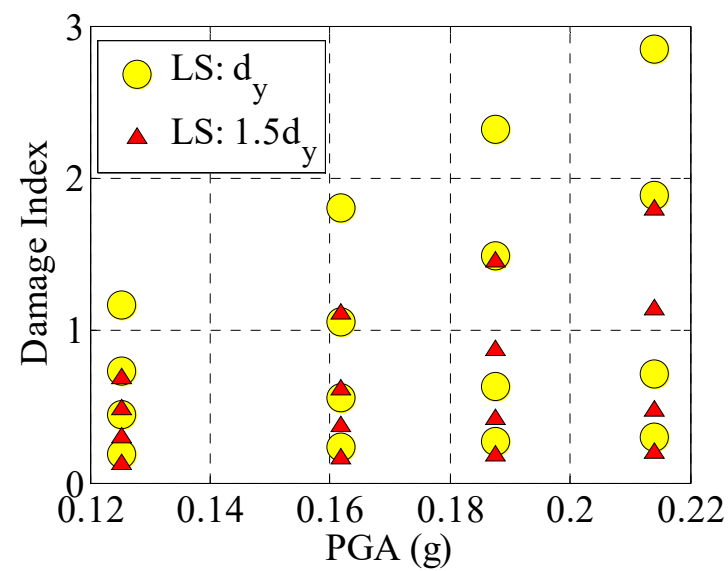

(a)

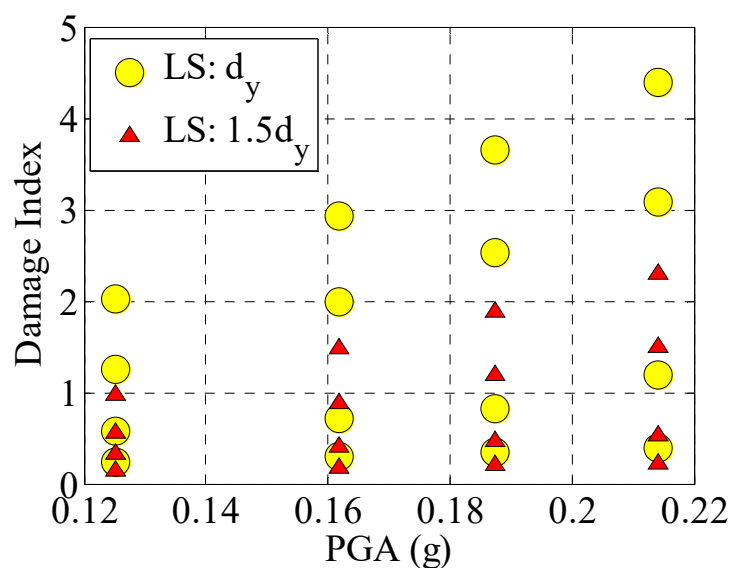

(b)

Figure 9. Damage indices obtained from the proposed procedure applied to the one-story frame carried out from (a) Morandi et al. (2018) [20]; (b) Pires et al. (1990) [17].

From the plots clearly emerge the cases where the selected limit state of the infill is still attained for PGA values corresponding to low returns periods. Precisely these cases require particular attention, since the damage of infills could lead to a loss of the efficacy of interventions provided for improving the energy efficiency of buildings by leading to a significant economic loss.

From the plots, as expected, also emerges the influence of the characteristics of the infill on the damage index. Indeed, from Figure 3, the greater strength of the infill panel in the case of Morandi (2018) [20] with respect to the case of Pires (1990) [17] is evident: this is the main parameter governing the vulnerability of masonry infills. Then, in order to better underline this aspect, the procedure has been applied by considering the configuration of the bare frame analyzed by Morandi et al. (2018) [20] and introducing the characteristics of the infill accounted in the study carried out in [17]. Two sets of analyses have been performed by considering respectively the case with a period equal to $0.1 \mathrm{~s}$ and a period equal to $0.2 \mathrm{~s}$. The results reported in Figure 10 underline differences in terms of Damage Index with respect to both the infilled frame of Morandi et al. (2018) [20] and Pires et al. (1990) [17]. 


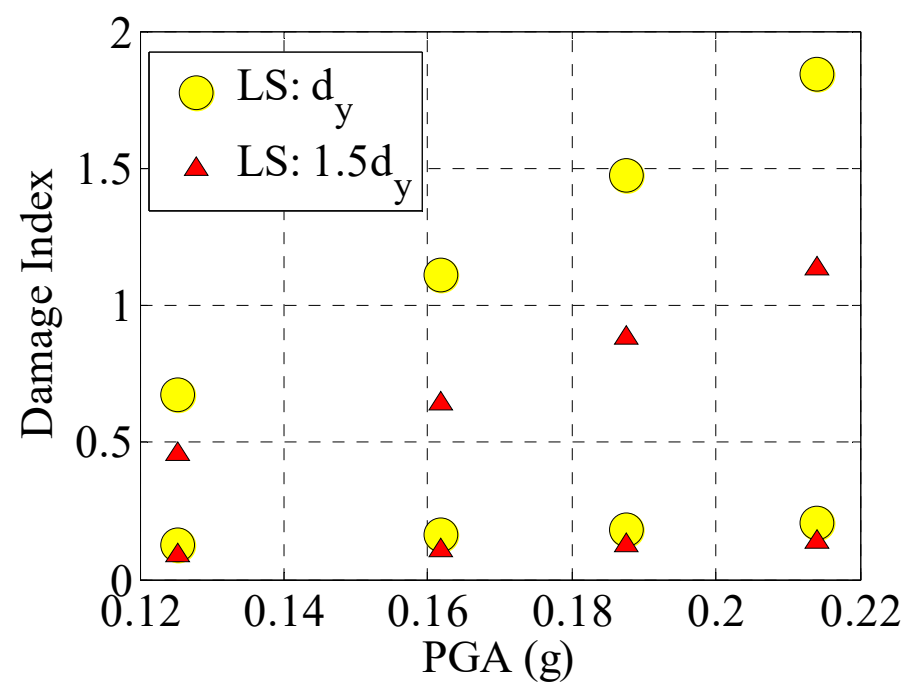

Figure 10. Damage indices obtained from the proposed procedure applied by considering the bare frame of Morandi et al. (2018) [20] and the characteristics of the infill of Pires et al. (1990) [17].

Indeed, comparing the results of Figure 10 with the corresponding ones of Figure 9, it is possible to observe a variation of Damage Indices with respect to both the infilled frame of Morandi et al. (2018) [20] and the infilled frame of Pires et al. (1990) [17].

This underlines the importance of considering the interaction between the RC frame and the infill in evaluating the damage status of the infill itself toward seismic actions. One of the main features of the proposed procedure is to specifically consider the whole behavior of the infilled frame in order to derive information on the damage state of the infill.

\section{Conclusions}

The damage exhibited by infill panels of RC frames during earthquakes underline the vulnerability of such nonstructural elements toward seismic actions. In particular, since in recent years, many interventions for improving the energy efficiency of buildings directly involve infill elements, the knowledge of the level of vulnerability of infills toward seismic actions certainly plays an important role.

In the present paper, the authors have carried out a simple procedure based on the common pushover analysis procedure for correlating the beginning of damaging of infills to the expected seismic action. To this end, a preliminary study devoted to identifying a reliable model for simulating the monotonic and cyclic response of infills has been carried out. In particular, the reliability of the selected models, opportunely combined among them, has been assessed with reference to some experimental cases. Consequently, the same models have been introduced in the proposed procedure for deducing the information about the damage state of infills toward seismic actions characterized by different period of returns.

The obtained results have underlined the cases where the accounted level of damage of infills occurs for low levels of seismic actions, i.e., the ones corresponding to low values of the return period. This underlines the significant vulnerability of infills and, then, the need of providing strengthening interventions before applying on the infill expensive systems for improving the energy efficiency of buildings.

The proposed procedure could represent a useful tool for a preliminary assessment of the seismic response of infill panels of RC frames toward seismic actions.

Author Contributions: Conceptualization, E.G.; methodology, E.G.; software, E.G.; validation, E.G., M.B. and G.M.; formal analysis, E.G., M.B. and G.M.; investigation, E.G., M.B. and G.M.; data curation, E.G., M.B. and G.M.; writing-original draft preparation, E.G., M.B. and G.M.; writing-review and editing, E.G., M.B. and G.M.; visualization, E.G., M.B. and G.M.; supervision, E.G. All authors have read and agreed to the published version of the manuscript. 
Funding: This research received no external funding.

Data Availability Statement: The Data accounted in this study for developing the numerical analyses were derived from the cited literature.

Conflicts of Interest: The authors declare no conflict of interest.

\section{References}

1. De Risi, M.T.; Del Gaudio, C.; Ricci, P.; Verderame, G.M. In-plane behaviour and damage assessment of masonry infills with hollow clay bricks in RC frames. Eng. Struct. 2018, 168, 257-275. [CrossRef]

2. Polyakov, S.V. On the interaction between masonry filler walls and enclosing frame when loaded in the plane of the wall. Transl. Earthq. Eng. 1960, 2, 36-42.

3. Holmes, M. Steel frames with brickwork and concrete infilling. Proc. Inst. Civ. Eng. 1961, 19, 473-478. [CrossRef]

4. Stafford-Smith, B.; Carter, C. A method of analysis for infilled frames. Proc. Inst. Civ. Eng. 1969, 44, 31-48. [CrossRef]

5. Klingner, R.E.; Bertero, V.V. Earthquake resistance of infilled frames. J. Struct. Div. 1978, 104, 973-989. [CrossRef]

6. Mainstone, R.J. On the stiffnesses and strengths of infilled frames. Proc. Inst. Civ. Eng. 1971, 49 (Suppl. IV), 57-90.

7. FEMA. FEMA-274 Nehrp Commentary on the Guidelines for the Seismic Rehabilitation of Buildings; Federal Emergency Management Agency: Washington, DC, USA, 1997.

8. FEMA. FEMA-306 Evaluation of Earthquake Damaged Concrete and Masonry Wall Buildings, Basic Procedures Manual; Federal Emergency Management Agency: Washington, DC, USA, 1999.

9. FEMA. FEMA-356 Prestandard and Commentary for the Seismic Rehabilitation of Buildings; Federal Emergency Management Agency: Washington, DC, USA, 2000.

10. Abdul-Kadir, M.R. The Structural Behaviour of Masonry Infill Panels in Framed Structures. Ph.D. Thesis, Department of Civil Engineering and Building Science, University of Edinburgh, Edinburgh, UK, 1974.

11. Crisafulli, F.J. Seismic Behaviour of Reinforced Concrete Structures with Masonry Infills. Ph.D. Thesis, Department of Civil Engineering, University of Canterbury, Christchurch, New Zealand, 1997.

12. Noh, N.M.; Liberatore, F.M.; Tesfamariam, S. Modelling of masonry infilled RC frames subjected to cyclic loads: State of the art review and modelling with OpenSees. Eng. Struct. 2017, 150, 599-621. [CrossRef]

13. Huang, H.; Burton, H.V.; Sattar, S. Development and Utilization of a Database of Infilled Frame Experiments. Am. Soc. Civ. Eng. Numer. Model. 2020. [CrossRef]

14. Lowes, L.; Mitra, N.; Altoontash, A. A Beam-Column Joint Model for Simulating the Earthquake Response of Reinforced Concrete Frames; PEER Report No. 2003/10; Pacific Earthquake Engineering Research Center: Berkeley, CA, USA, 2004.

15. Mckenna, F.; Fenves, G.; Scott, M.; Jeremic, B. Open System for Earthquake Engineering Simulation; OpenSees: Berkley, CA, USA, 2000.

16. MATLAB, Version 9.7.0.1190202 (R2019b); The MathWorks Inc.: Natick, MA, USA, 2018.

17. Pires, F. Influence of Masonry Walls over the Behaviour of Reinforced Concrete Frames under Horizontal Actions. Ph.D. Thesis, National Laboratory in Civil Engineering, Lisbon, Portugal, 1990. (In Portugueses).

18. Karayannis, C.G.; Demetrios, K.; Favvata, M.J. Behavior of Bare and Masonry Infilled R/C Frames under Cyclic Loading. Experiments and Analysis. WIT Trans. Built Environ. 2005, 81, 1-10. [CrossRef]

19. Stylianidis, K. Experimental investigation of masonry infilled R/C frames. Open Constr. Build. Technol. J. 2012, 6, 194-212. [CrossRef]

20. Morandi, P.; Hak, S.; Magenes, G. Performance-based interpretation of in-plane cyclic tests on RC frames with strong masonry infills. Eng. Struct. 2018. [CrossRef]

21. Gulkan, P.; Sozen, M. Inelastic response of reinforced concrete structures. ACI J. 1974, 71, 604-610.

22. Shibata, A.; Sozen, M. Substitute structure method for seismic design in reinforced concrete. J. Struct. Div. 1976, 102, 3548-3566. [CrossRef]

23. Grande, E.; Rasulo, A. A simple approach for seismic retrofit of low-rise concentric X-braced steel frames. J. Constr. Steel Res. 2015, 107, 162-172. [CrossRef]

24. Grande, E.; Rasulo, A. Seismic Assessment of Concentric X-Braced Steel Frames. Eng. Struct. 2013, 49, 983-995. [CrossRef] 